\title{
PENGARUH APLIKASI KOMPOS KOTORAN SAPI DAN PAITAN TERHADAP SIFAT KIMIA TANAH DAN PERTUMBUHAN TANAMAN KEDELAI
}

\section{Effect of Application of Cow Dung and Tithonia Compost on Soil Chemical Properties and Growth of Soybean}

\author{
Putri Alfira Zuraida ${ }^{*}$, Yulia Nuraini \\ 1)Jurusan Tanah, Fakultas Pertanian, Universitas Brawijaya, Jl. Veteran No. 1, Malang 65145 \\ ${ }^{*}$ Penulis korespondensi: putrialfirazuraida@gmail.com
}

\begin{abstract}
Fertile agricultural land encourages people to carry out agricultural cultivation activities. But in general, it has decreased soil fertility because its managed intensively without recycling of organic matter and has an impact on decreasing soil fertility chemically such as soil organic carbon and $\mathrm{pH}$ then leads to low productivity. Soybean is an agricultural product that necessary to develop because the demand for soybean consumption in East Java Province has always increased. However, Indonesia has not been able to fulfil this demand. One of the technology innovations that can be applied to improve soil fertility that has low organic matter and to increasing soybean production by providing input of quality organic fertilizer in the form of compost (Tithonia and Cow Dung). So this research is important to determine the effect of application cow dung compost and tithonia on soil chemical properties, the growth of soybean crops, and the correlations between soil chemical properties and soybean growth. This study used a randomized block design with 6 treatments and 3 replications. The result showed that the application of tithonia and cow dung compost shows a significant effect on soil chemical properties, plant height, and the number of leaves, but didn't show a significant effect on the number of branches in every observation. Based on the correlation analysis, the results show a positive correlation between soil chemical properties and soybean growth.
\end{abstract}

Keywords: composting, organic fertilizer, soil fertility, soybean production

\section{Pendahuluan}

Kegiatan budidaya pertanian di Indonesia pada umumnya dilakukan di lahan kering, akan tetapi kegiatan budidaya pada agroekosistem tersebut umumnya masih diikuti dengan rendahnya produksi yang berkaitan dengan rendahnya produktivitas lahan. Salah satu upaya yang dilakukan di lahan kering guna meningkatkan produktivitasnya yaitu dengan melakukan pengolahan lahan secara intensif. Pengolahan lahan secara intensif serta budidaya monokultur tanpa rotasi dan pendaur ulang bahan organik menyebabkan hilangnya bahan organik tanah, degradasi tanah, dan penurunan produktivitas lahan (Wahyunie et al., 2012). Potensi lahan kering untuk pengembangan pertanian cukup besar, sehingga perlu adanya perhatian khusus untuk mengembangkan produk pertanian dengan memanfaatkan dan mengembangkan berbagai inovasi teknologi. Tanaman kedelai merupakan salah satu tanaman yang penting dalam pemenuhan kebutuhan pangan dalam rangka perbaikan gizi masyarakat karena kedelai menjadi sumber protein nabati yang relatif murah dibandingkan yang lain seperti daging, susu, dan ikan. Menurut Rohmah dan Saputro (2016), biji kedelai memiliki kadar protein kurang lebih sebanyak 35\%, karbohidrat 15\%, dan lemak 15\%, kedelai juga memiliki kandungan mineral seperti kalsium, fosfor, besi, vitamin $A$, dan B. Banyaknya manfaat yang dimiliki kedelai membuat kedelai menjadi salah 


\section{Jurnal Tanah dan Sumberdaya Lahan Vol 8 No 1: 123-133, 2021 e-ISSN:2549-9793, doi: 10.21776/ub.jts1.2021.008.1.16}

satu komoditas pertanian yang menjadi perhatian masyarakat Hal ini dibuktikan dengan data Wahyuningsih (2019), yang mencantumkan bahwasannya konsumsi total kedelai khususnya di Provinsi Jawa Timur selalu meningkat mulai dari tahun 2014 hingga 2018 dengan peningkatan rata-rata sebesar 2,90\%. Permintaan kedelai di Indonesia pada tahun 2019 sebesar 2,49 juta ton, sedangkan hasil produksinya masih rendah yaitu 1,46 juta ton. Hal ini membuktikan bahwa Indonesia belum mampu mencukupi permintaan pemenuhan konsumsi kedelai sehingga rata-rata $65 \%$ dari total penyediaan kedelai berasal dari impor.

Tanah yang mulai menurun kesuburannya masih berpotensi untuk budidaya kedelai dengan beberapa teknologi dan inovasi yang digunakan salah satunya yaitu dengan aplikasi pupuk organik berupa kompos yang berkualitas dari kotoran sapi dan tanaman paitan agar dapat memperbaiki kondisi tanah yang mulai menurun tingkat kesuburannya sehingga dapat sesuai dengan syarat tumbuh tanaman kedelai. Penggunaan bahan organik kotoran sapi dan paitan karena ketersediaannya yang melimpah dan memiliki manfaat pada peningkatan kesuburan tanah, sedangkan apabila tidak dimanfaatkan akan menjadi limbah yang dapat menimbulkan pencemaran lingkungan. Penelitian Muktiyanta et al. (2018), menunjukkan bahwa pemberian kotoran sapi dapat secara signifikan mempengaruhi tinggi tanaman dan panjang akar. Pada penelitian yang dilakukan oleh Refliaty et al. (2011), juga menyatakan bahwa pemberian kotoran sapi pada tanah Ultisols dapat meningkatkan hasil kedelai hingga 1,083 t ha $^{-1}$. Penggunaan tanaman paitan sebagai kompos dapat meningkatkan kandungan bahan organik tanah 39,4\% dibandingkan tanpa pemberian tanaman paitan. Pemberian paitan dapat meningkatkan hasil biji 17,3\% dibandingkan tanpa diberi pupuk paitan (Sumarni et al., 2012).

Ditinjau dari banyaknya manfaat yang dapat diberikan melalui aplikasi pupuk organik yaitu kompos kotoran sapi dan paitan maka penelitian ini bertujuan untuk 1) Mengetahui dan menganalisis pengaruh aplikasi kombinasi kompos kotoran sapi dan kompos paitan terhadap sifat kimia tanah, 2) Mengetahui dan menganalisis pengaruh aplikasi kombinasi kompos kotoran sapi dan kompos paitan terhadap pertumbuhan tanaman kedelai, 3) Mengetahui dan menganalisis hubungan antara parameter sifat kimia tanah dan pertumbuhan tanaman kedelai.

\section{Bahan dan Metode}

\section{Tempat dan waktu penelitian}

Penelitian ini dilaksanakan pada bulan Februari - Juli 2020. Terdapat dua tahap pelaksanaan penelitian. Tahap pertama yaitu pembuatan kompos yang dilaksanakan di UPT Kompos Fakultas Pertanian Universitas Brawijaya Malang. Tahap dua yaitu analisis tanah dan penanaman tanaman kedelai dilakukan di Laboratorium Kimia Tanah FP UB dan Greenhouse Jatimulyo Malang serta pengambilan sampel tanah yang berlokasi di Agrotechno Park Jatikerto Universitas Brawijaya

\section{Rancangan percobaan}

Pada penelitian tahap 1 menggunakan Rancangan Acak Kelompok (RAK), terdiri atas 5 perlakuan (Tabel 1) dan diulang sebanyak 3 kali sehingga didapatkan 15 satuan percobaan.

Tabel 1. Perlakuan pembuatan kompos sapi dan paitan.

\begin{tabular}{ccl}
\hline No & Kode & \multicolumn{1}{c}{ Perlakuan } \\
\hline 1 & P1 & $15 \mathrm{~kg} \mathrm{P}$ \\
2 & P2 & $15 \mathrm{~kg} \mathrm{KS}$ \\
3 & P3 & $11,25 \mathrm{~kg} \mathrm{P}+3,75 \mathrm{~kg} \mathrm{KS}$ \\
4 & P4 & $7,5 \mathrm{~kg} \mathrm{P}+7,5 \mathrm{~kg} \mathrm{KS}$ \\
5 & P5 & $3,75 \mathrm{~kg} \mathrm{P}+11,25 \mathrm{~kg} \mathrm{KS}$ \\
\hline
\end{tabular}

Keterangan: KS (Kotoran Sapi); P (Paitan)

Pada penelitian tahap 2 menggunakan Rancangan Acak Kelompok (RAK), terdiri atas 6 perlakuan (Tabel 2) dan diulang sebanyak 3 kali sehingga didapatkan 18 satuan percobaan.

\section{Pelaksanaan penelitian}

\section{Pembuatan kompos kotoran sapi dan paitan}

Bahan utama dalam proses pengomposan ini yaitu kotoran sapi dan paitan yang didapatkan di peternakan sapi Sumber Sekar dan di lahan Jatimulyo. Kotoran sapi segar yang dibutuhkan yaitu sebanyak $200 \mathrm{~kg}$ sedangkan tumbuhan paitan segar yang dibutuhkan yaitu sebanyak 400 $\mathrm{kg}$. 


\section{Jurnal Tanah dan Sumberdaya Lahan Vol 8 No 1: 123-133, 2021 e-ISSN:2549-9793, doi: 10.21776/ub.jts1.2021.008.1.16}

Tabel 2. Perlakuan aplikasi kompos kotoran sapi dan paitan.

\begin{tabular}{ccl}
\hline No & Kode & \multicolumn{1}{c}{ Perlakuan } \\
\hline 1 & P0 & Kontrol (Tanpa kompos) \\
2 & P1 & $100 \% \mathrm{KP}$ \\
3 & P2 & $100 \% \mathrm{KKS}$ \\
4 & $\mathrm{P} 3$ & $75 \% \mathrm{KP}+25 \% \mathrm{KKS}$ \\
5 & $\mathrm{P} 4$ & $50 \% \mathrm{KP}+50 \% \mathrm{KKS}$ \\
6 & $\mathrm{P} 5$ & $25 \% \mathrm{KP}+75 \% \mathrm{KKS}$ \\
\hline
\end{tabular}

Keterangan: KKS (Kompos Kotoran Sapi); KP (Kompos Paitan); Dosis kompos yang diberikan adalah $10 \mathrm{t} \mathrm{ha}^{-1}$ atau setara dengan $20 \mathrm{~g}_{\text {polybag- }}$.

Pengomposan yang dilakukan menggunakan metode Berkeley untuk kombinasi kompos paitan dan kotoran sapi, sedangkan pada bahan kompos tanpa kombinasi menggunakan metode Heap (Setyorini et al., 2006). Pengomposan dilakukan dengan mencacah bahan dengan ukuran $1,25-3,75 \mathrm{~cm}$ agar dapat terdekomposisi dengan cepat. Bahan yang sudah dikering anginkan di campur dengan air 30-40\% dari total bahan yang digunakan $( \pm 5 \mathrm{~L})$ (Berlian et al., 2015), lalu dimasukkan kedalam kotak kompos yang terbuat dari kayu dengan ukuran $25 \times 25 \times 90 \mathrm{~cm}$ dan ditutup menggunakan karung plastic. Kompos dibalik apabila suhu mencapai termofilik yaitu $45-65^{\circ} \mathrm{C}$, jika suhu melebihi $71^{\circ} \mathrm{C}$ maka mikroorganisme akan mati.

\section{Pengambilan sampel tanah}

Pengambilan sampel tanah dilakukan di Agrotechno Park Universitas Brawijaya yang terletak di Desa Jatikerto, Kecamatan Kromengan, Kabupaten Malang yang berjenis tanah Alfisol (Nuraini, 2012). Sampel tanah diambil pada kedalaman $0-20 \mathrm{~cm}$ kemudian dikering anginkan. Selanjutnya tanah diayak menggunakan ayakan yang berdiameter $2 \mathrm{~mm}$ dan $0,5 \mathrm{~mm}$ untuk media tanam dan analisis laboratorium. Sebelum penelitian dilakukan maka dilakukan analisis dasar $\left(\mathrm{pH} \mathrm{H}_{2} \mathrm{O}, \mathrm{N}\right.$-total, C-organik, P tersedia, K-dd, KTK, Tekstur tanah, Berat isi, Berat jenis, $\mathrm{KA} \mathrm{pF} 2,5$, dan KA $\mathrm{pF} 4,2)$.

Tahap dua (aplikasi kompos kotoran sapi dan paitan serta penanaman kedelai)

Tanah yang sudah dikering anginkan dan lolos ayakan $2 \mathrm{~mm}$ di campur dengan kompos yang sudah matang lalu dimasukkan ke dalam polybag ukuran $5 \mathrm{~kg}$ (20,3 $\mathrm{g}$ polybag-1), selanjutnya tanaman kedelai ditanam di Greenhouse Jatimulyo menggunakan varietas Dega 1. Benih tanaman diberi inokulasi Rbizobium merek Agrisoy dengan cara membasahi benih dengan air bersih kemudian menambahkan inokulum Rhizobium dengan dosis $20 \mathrm{~g} / \mathrm{kg}$ benih selama 15 menit. Benih yang telah diberi inokulum dikering anginkan lalu siap untuk ditanam dalam polybag dengan sejumlah 2 benih polybag-1.

\section{Pemeliharaan tanaman kedelai}

Terdapat beberapa kegiatan pemeliharaan yang dilakukan yaitu penyiraman yang dilakukan setiap hari pada pagi hari sesuai dengan kapasitas lapang yang telah diukur $(1,4 \mathrm{~L})$, penjarangan yang dilakukan satu minggu setelah tanam dengan cara mengurangi populasi tanaman dan menyisakan satu tanaman yang pertumbuhannya paling baik, penyiangan dilakukan secara manual dengan tujuan untuk membuang gulma yang tumbuh di sekitar tanaman, pemupukan anorganik pada awal tanam sebagai starter yaitu SP36 $100 \mathrm{~kg} \mathrm{ha}^{-1}$ pada waktu tanam, urea $75 \mathrm{~kg} \mathrm{ha}^{-1}$, dan $\mathrm{KCl} 100 \mathrm{~kg}$ ha $^{-1}$ pada waktu tujuh hari setelah tanam, serta pengendalian hama yang dilakukan yaitu secara fisik dengan mengambil hama yang ada pada tanaman kedelai dan kimiawi menggunakan pestisida Curacorn dengan dosis $0,5 \mathrm{~mL} \mathrm{~L}^{-1}$ air pada umur 21 HST hingga 28 HST

\section{Pengamatan tanaman kedelai}

Pengamatan tanaman kedelai dilakukan setiap satu minggu sekali $(14,21,28,35$, dan 42 HST) dengan mengamati faktor pertumbuhan seperti tinggi tanaman, jumlah daun, dan jumlah cabang. Tinggi tanaman diukur menggunakan meteran dari pangkal batang tanaman yang tumbuh di permukaan sampai pada titik tumbuh batang. Jumlah daun dihitung secara manual pada daun trifoliate yang membuka sempurna. Jumlah cabang dilakukan dengan cara menghitung secara manual cabang yang tumbuh.

\section{Analisis kimia tanab}

Analisis kimia tanah dilakukan pada umur 0 dan 45 HST (Tabel 4). Analisis kimia tanah menggunakan sampel tanah komposit yang sudah dikering anginkan dan lolos ayakan $2 \mathrm{~mm}$ 


\section{Jurnal Tanah dan Sumberdaya Lahan Vol 8 No 1: 123-133, 2021 e-ISSN:2549-9793, doi: 10.21776/ub.jts1.2021.008.1.16}

dan $0,5 \mathrm{~mm}$. sampel tanah lolos ayakan $2 \mathrm{~mm}$ digunakan untuk analisis $\mathrm{pH}$ dan kadar air. Sampel tanah lolos yang ayakan $0,5 \mathrm{~mm}$ digunakan untuk analisis C-organik dan K-dd.

\section{Analisis data}

Data hasil penelitian tahap 1 dan 2 di analisis menggunakan analisis sidik ragam atau Analysis of Variance (ANOVA) dengan uji $\mathrm{F}$ taraf $5 \%$ menggunakan aplikasi GENSTAT 20.1. Apabila hasil yang didapatkan berpengaruh nyata maka dilakukan uji lanjut Duncan Multiple Range Test (DMRT) taraf 5\%. Selanjutnya, untuk mencari hubungan antar parameter pada penelitian tahap 2 dilakukan uji korelasi.

\section{Hasil dan Pembahasan}

\section{Karakteristik tanah dan kompos}

Tanah yang digunakan dalam penelitian merupakan jenis tanah Alfisol (Darmawan dan Soemarno, 2000) yang diambil dari Agrotechno Park Jatikerto Universitas Brawijaya. Analisis dasar pada tanah digunakan sebagai acuan untuk mengetahui kondisi tanah awal sebelum diberi perlakuan. Hasil analisis dasar pada tanah yang digunakan sebagai media tanam dalam penelitian disajikan pada (Tabel 3). Kondisi tanah yang kurang subur tersebut tidak dapat mendukung pertumbuhan tanaman kedelai yang membutuhkan bahan organik tanah sebesar 3 $5 \%$ (sedang sampai tinggi), unsur hara $\mathrm{N}$ yang tinggi yaitu $0,21-0,75 \%$, unsur $P$ tinggi yaitu 11 - 15 ppm; unsur $\mathrm{K}$ tinggi yaitu $0,6-1$ me $100 \mathrm{~g}$ ${ }^{1}$ dan $\mathrm{pH}$ sebesar 6,0 - 6,5 (Sumarno dan ahmad, 2016). Hal tersebut sesuai dengan penelitian (Taufiq dan Sundari, 2012), bahwa tanah yang memiliki $\mathrm{pH}$ rendah $<6$ tergolong masam, dan umumnya memiliki $\mathrm{Al}$ yang tinggi. Kondisi $\mathrm{Al}$ yang tinggi dan $\mathrm{pH}$ rendah ini tidak hanya berpengaruh langsung terhadap tanaman kedelai saja, tetapi juga berpengaruh terhadap ketersediaan hara bagi tanaman. Guna meningkatkan unsur hara pada tanah Alfisol di atas maka dilakukan pengaplikasian pupuk organik yaitu kompos paitan dan kotoran sapi yang telah dikomposkan selama 30 hari dan dianalisis untuk mengetahui kualitas kompos tersebut apakah sudah sesuai dengan persyaratan teknis minimal mutu pupuk organik padat berdasarkan Kepmentan Nomor 261/KPTS/SR.310/M/4/2019.

Tabel 3. Hail analisis dasar tanah.

\begin{tabular}{clcc}
\hline No & Parameter & Nilai & Kriteria* \\
\hline 1 & pH & 5,49 & Masam \\
2 & C-organik (\%) & 0,85 & Sangat Rendah \\
3 & Bahan Organik (\%) & 1,46 & Sangat Rendah \\
4 & N total (\%) & 0,08 & Sangat Rendah \\
5 & P Tersedia $\left(\mathrm{ppm}^{\circ}\right)$ & 3,77 & Sangat Rendah \\
6 & K-dd (me $\left.100 \mathrm{~g}^{-1}\right)$ & 0,74 & Tinggi \\
7 & KTK (me $\left.100 \mathrm{~g}^{-1}\right)$ & 19,85 & Sedang \\
8 & Tekstur tanah & 1,23 & - \\
9 & Berat isi $\left(\mathrm{g} \mathrm{cm}^{-3}\right)$ & 2,50 & - \\
10 & Berat jenis $\left(\mathrm{g} \mathrm{cm}^{-3}\right)$ & 0,41 & - \\
11 & Kadar air pF 2,5 $\left(\mathrm{g} \mathrm{g} \mathrm{g}^{-1}\right)$ & 0,13 & - \\
12 & Kadar air pF 4,2 $\left(\mathrm{g} \mathrm{g}^{-1}\right)$ & Lempung liat berdebu & - \\
\hline
\end{tabular}

Keterangan: *: Kriteria Berdasarkan Balai P \{enelitian Tanah (2005).

Hasil analisis kimia kompos yang disajikan pada Tabel 4 menunjukkan bahwa kompos paitan dan kotoran sapi yang telah matang. Kompos tersebut diuji kualitasnya berdasarkan Kepmentan Nomor 261/ KPTS/SR.310/M/4/2019. Kompos dengan kombinasi kotoran sapi dan paitan memiliki kualitas yang telah sesuai dengan persyaratan teknis minimal mutu pupuk organik padat. Kompos yang sudah matang tersebut sudah dapat diaplikasikan ke tanaman sebagai bahan penyubur tanah. 


\section{Jurnal Tanah dan Sumberdaya Lahan Vol 8 No 1: 123-133, 2021 e-ISSN:2549-9793, doi: 10.21776/ub.jts1.2021.008.1.16}

Tabel 4. Hasil analisis sifat kimia kompos paitan dan kotoran sapi.

\begin{tabular}{lccccc}
\hline Perlakuan & pH & C-organik (\%) & N total (\%) & Rasio C/N & K total (\%) \\
\hline P1 $(100 \% \mathrm{P})$ & 8,02 & 15,31 & 1,92 & 8,10 & 3,65 \\
P2 $(100 \% \mathrm{KS})$ & 7,49 & 29,16 & 1,85 & 17,55 & 1,86 \\
P3 $(75 \% \mathrm{P}+25 \% \mathrm{KS})$ & 7,79 & 27,31 & 2,08 & 10,18 & 2,62 \\
P4 $(50 \% \mathrm{P}+50 \% \mathrm{KS})$ & 7,94 & 28,28 & 2,16 & 13,08 & 2,72 \\
P5 $(25 \% \mathrm{P}+75 \% \mathrm{KS})$ & 7,87 & 26,64 & 2,46 & 10,84 & 2,91 \\
\hline Kepmentan 2019 & $4-9$ & $\geq 15$ & $\geq 2$ & $\leq 25$ & $\geq 2$ \\
\hline
\end{tabular}

Keterangan: $\mathrm{P}=$ Paitan, $\mathrm{KS}=$ Kotoran Sapi.

Penggunaan kompos yang belum matang akan menyebabkan dekomposisi pada kondisi anaerobik, hal tersebut akan menghasilkan senyawa fitotoksik dari asam-asam organik seperti amonia, nitrit-nitrogen, besi, dan mangan, oleh karena itu penggunaan kompos harus sesuai dengan standar baku mutu yang telah ditentukan (Setyorini et al., 2006).

\section{Sifat kimia tanah}

pH tanah

$\mathrm{pH}$ merupakan derajat kemasaman yang dapat mempengaruhi ketersediaan unsur hara yang lain. Berikut merupakan hasil analisis $\mathrm{pH}$ tanah yang sudah diberi perlakuan kompos paitan dan kotoran sapi disajikan pada Tabel 5.

Tabel 5. Pengaruh pemberian kompos paitan dan kotoran sapi terhadap ph tanah.

\begin{tabular}{lcc}
\hline Perlakuan & \multicolumn{2}{c}{ Nilai pH } \\
\cline { 2 - 3 } & 0 HST & 45 HST \\
\hline P0 (Kontrol) & $5,49 \mathrm{a}$ & $5,88 \mathrm{a}$ \\
P1 (100\% Kompos Paitan) & $5,87 \mathrm{bc}$ & $6,20 \mathrm{c}$ \\
P2 (100\% Kompos Kotoran Sapi) & $5,79 \mathrm{~b}$ & $6,15 \mathrm{bc}$ \\
P3 (75\% Kompos Paitan + 25\% Kompos Kotoran Sapi) & $5,89 \mathrm{bc}$ & $6,02 \mathrm{ab}$ \\
P4 (50\% Kompos Paitan + 50\% Kompos Kotoran Sapi) & $5,92 \mathrm{bc}$ & $6,22 \mathrm{c}$ \\
P5 (25\% Kompos Paitan + 75\% Kompos Kotoran Sapi) & $5,96 \mathrm{c}$ & $6,20 \mathrm{c}$ \\
\hline
\end{tabular}

Keterangan: angka yang diikuti oleh huruf yang sama pada kolom yang sama menunjukkan hasil tidak berbeda nyata menurut uji DMRT taraf 5\%.

Hasil analisis ragam (ANOVA) menunjukkan bahwa pemberian kombinasi kompos paitan dan kotoran sapi memberikan pengaruh nyata terhadap peningkatan $\mathrm{pH}$ tanah 0 HST dan 45 HST. Pada analisis $\mathrm{pH} 0$ HST perbedaan nyata dapat dilihat pada nilai $\mathrm{pH}$ tertinggi yaitu pada perlakuan $\mathrm{P} 5$ dengan nilai sebesar 5,96 (nilai $\mathrm{pH}$ kompos 7,87) dan terendah yaitu pada perlakuan $\mathrm{P} 0$ yaitu sebesar 5,49. Peningkatan $\mathrm{pH}$ tersebut karena adanya masukan bahan organik berupa kompos ke dalam tanah. Pernyataan tersebut selaras dengan penelitian Arifiati et al. (2017), yang menyatakan bahwa pemberian pupuk kompos dapat meningkatkan $\mathrm{pH}$ tanah serta memperbaiki $\mathrm{pH}$ pada tanah masam dalam jangka waktu yang panjang. Pada analisis $\mathrm{pH}$ tanah 45 HST juga menunjukkan hasil berbeda nyata dengan nilai $\mathrm{pH}$ tertinggi yaitu pada perlakuan $\mathrm{P} 4$ dengan nilai $\mathrm{pH}$ sebesar 6,22 dan terendah pada perlakuan $\mathrm{P} 0$ dengan nilai $\mathrm{pH}$ sebesar 5,88. Berdasarkan Tabel 5 dapat dilihat bahwasannya terjadi peningkatan dari $\mathrm{pH} 0 \mathrm{HST}$ ke $\mathrm{pH} 45$ HST karena adanya dekomposisi lanjut dari kompos. Sejalan dengan penelitian Agustin dan Retno (2018), yang menyatakan bahwa dekomposisi lanjut dari pupuk kadang sapi pada kurun waktu penanaman telah melepaskan ion-ion $\mathrm{OH}^{-}$dari kompleks jerapannya sehingga berakibat pada peningkatan pH tanah. Antonius et al. (2018), juga menyatakan bahwa proses dekomposisi bahan organik mempengaruhi peningkatan $\mathrm{pH}$ tanah karena saat proses dekomposisi bahan organik menghasilkan asam-asam organik yang bersifat amfoter sehingga mampu meningkatkan $\mathrm{pH}$ tanah. 


\section{Jurnal Tanah dan Sumberdaya Lahan Vol 8 No 1: 123-133, 2021 e-ISSN:2549-9793, doi: 10.21776/ub.jts1.2021.008.1.16}

\section{Kandungan C-organik tanah}

C-organik tanah merupakan bagian dari bahan organik tanah yang memiliki fungsi dan peran penting dalam menentukan kesuburan dan produktivitas tanah melalui pengaruhnya terhadap sifat fisik, kimia, dan biologi tanah. Hasil analisis C-organik tanah setelah diberi perlakuan kompos paitan dan kotoran sapi dapat dilihat pada Tabel 6. Hasil analisis ragam (ANOVA) menunjukkan bahwa pemberian kombinasi kompos paitan dan kotoran sapi berpengaruh nyata terhadap peningkatan $\mathrm{C}$ organik tanah 0 HST dan 45 HST. Rerata C- organik tanah 0 HST tertinggi yaitu pada perlakuan P4 sebesar 1,48\% (nilai C-organik kompos 28,28\%) dan berbeda nyata dengan rerata terendah yaitu pada perlakuan P0 (kontrol) sebesar $0,93 \%$ yang artinya penambahan kombinasi kompos paitan dan kotoran sapi dengan perbandingan 50:50 dapat meningkatkan kandungan C-organik tanah sebesar 59,1\%. Hal ini sesuai dengan penelitian Widodo dan Kusuma (2018), bahwa pemberian berbagai dosis kompos pada tanah dapat berpengaruh nyata terhadap C-organik tanah pada awal, awal pertumbuhan generatif, dan saat panen.

Tabel 6. Pengaruh pemberian kompos paitan dan kotoran sapi terhadap C-organik tanah.

\begin{tabular}{llc}
\hline Perlakuan & \multicolumn{2}{c}{ C-organik Tanah (\%) } \\
\cline { 2 - 3 } & 0 HST & 45 HST \\
\hline P0 (Kontrol) & $0,93 \mathrm{a}$ & $0,85 \mathrm{a}$ \\
P1 (100\% Kompos Paitan) & $1,09 \mathrm{ab}$ & $1,14 \mathrm{ab}$ \\
P2 (100\% Kompos Kotoran Sapi) & $1,12 \mathrm{ab}$ & $1,35 \mathrm{~b}$ \\
P3 (75\% Kompos Paitan + 25\% Kompos Kotoran Sapi) & $1,34 \mathrm{bc}$ & $1,19 \mathrm{ab}$ \\
P4 (50\% Kompos Paitan + 50\% Kompos Kotoran Sapi) & $1,48 \mathrm{c}$ & $1,41 \mathrm{~b}$ \\
P5 (25\% Kompos Paitan + 75\% Kompos Kotoran Sapi) & $1,40 \mathrm{bc}$ & $1,00 \mathrm{a}$ \\
\hline
\end{tabular}

Keterangan: angka yang diikuti oleh huruf yang sama pada kolom yang sama menunjukkan hasil tidak berbeda nyata menurut uji DMRT taraf 5\%.

Pada analisis C-organik 45 HST juga menunjukkan hasil yang berpengaruh nyata pada perlakuan pemberian kompos paitan dan kotoran sapi. Rerata tertinggi didapatkan pada perlakuan P4 dengan nilai sebesar 1,41\% berbeda nyata dengan rerata terendah pada perlakuan kontrol yaitu sebesar $0,85 \%$, namun perlakuan P4 tidak berbeda nyata dengan perlakuan P1, P2, dan P3. Menurut Afandi et al. (2015), adanya penambahan bahan organik berbanding lurus dengan peningkatan C-organik tanah dan penahan lengas tanah. Karbon merupakan sumber makanan bagi mikroorganisme tanah, sehingga keberadaan Corganik dapat memacu aktivitas mikroorganisme serta meningkatkan proses dekomposisi tanah dan reaksi-reaksi yang memerlukan bantuan mikroorganisme, misalnya pelarut $\mathrm{P}$ dan fiksasi $\mathrm{N}$.

\section{Kalium dapat ditukar (K-dd)}

Kalium merupakan unsur hara esensial yang dibutuhkan dalam jumlah yang banyak oleh tanaman. Kalium berfungsi untuk pembentukan dan transfer karbohidrat dalam tanaman, fotosintesis, serta sintesis protein (Handayanto et al., 2017) Hasil analisis K-dd tanah setelah diberi perlakuan kompos paitan dan kotoran sapi dapat dilihat pada Tabel 7. Berdasarkan hasil analisis ragam (ANOVA) menunjukkan bahwa pemberian kombinasi kompos paitan dan kotoran sapi berpengaruh nyata terhadap peningkatan kalium tanah 0 HST dan 45 HST. K-dd pada 0 HST yang tertinggi pada perlakuan P1 sebesar 1,84 me $100 \mathrm{~g}^{-1}$ dan berbeda nyata dengan perlakuan terendah yaitu P0 yang memiliki nilai K-dd sebesar 0,64 me $100 \mathrm{~g}^{-1}$, namun perlakuan P1 tidak berbeda nyata dengan perlakuan P3, P4, dan P5. Perlakuan P1 (100\% kompos paitan) memiliki kandungan Kdd tertinggi karena kompos yang diaplikasikan mengandung $\mathrm{K}$ total tertinggi di antara perlakuan lainnya yaitu sebesar 3,65\%. Menurut Lestari (2016), paitan mengandung 2,7-3,59\% N; $0,14-0,47 \%$ P; dan $0,25-4,10 \% \mathrm{~K}$, sehingga pemberian kompos paitan dapat mengurangi penggunaan dosis pupuk anorganik. 


\section{Jurnal Tanah dan Sumberdaya Lahan Vol 8 No 1: 123-133, 2021 e-ISSN:2549-9793, doi: 10.21776/ub.jts1.2021.008.1.16}

Tabel 7. Pengaruh pemberian kompos paitan dan kotoran sapi terhadap K-dd tanah.

\begin{tabular}{lcc}
\hline Perlakuan & \multicolumn{2}{c}{ Nilai K-dd ( $\mathbf{~ m e ~} \mathbf{1 0 0} \mathbf{~ g}^{-1}$ ) } \\
\cline { 2 - 3 } & 0 HST & 45 HST \\
\hline P0 (Kontrol) & $0,64 \mathrm{a}$ & $0,64 \mathrm{a}$ \\
P1 (100\% Kompos Paitan) & $1,84 \mathrm{c}$ & $1,33 \mathrm{c}$ \\
P2 (100\% Kompos Kotoran Sapi) & $1,15 \mathrm{ab}$ & $0,89 \mathrm{ab}$ \\
P3 (75\% Kompos Paitan + 25\% Kompos Kotoran Sapi) & $1,30 \mathrm{bc}$ & $1,13 \mathrm{bc}$ \\
P4 (50\% Kompos Paitan + 50\% Kompos Kotoran Sapi) & $1,49 \mathrm{bc}$ & $1,26 \mathrm{bc}$ \\
P5 (25\% Kompos Paitan + 75\% Kompos Kotoran Sapi) & $1,37 \mathrm{bc}$ & $1,06 \mathrm{bc}$ \\
\hline
\end{tabular}

Keterangan: angka yang diikuti oleh huruf yang sama pada kolom yang sama menunjukkan hasil tidak berbeda nyata menurut uji DMRT taraf 5\%.

Pada analisis ragam K-dd tanah 45 HST juga menunjukkan hasil bahwa pemberian kompos paitan dan kotoran sapi memberikan pengaruh nyata terhadap peningkatan K-dd. Rerata tertinggi didapatkan pada perlakuan P1 sebesar 1,33 me $100 \mathrm{~g}^{-1}$ dan berbeda nyata terhadap rerata terendah pada perlakuan P0 yaitu sebesar 0,64 me $100 \mathrm{~g}^{-1}$. Terdapat penurunan nilai $\mathrm{K}$-dd 0 HST dan 45 HST, hal ini karena kalium diserap oleh tanaman kedelai untuk menunjang pertumbuhannya. Hal ini sesuai dengan penelitian Yuwono et al. (2012), kadar kalium dapat berkurang karena diserap oleh tanaman. Afandi et al. (2015), juga menyatakan bahwa unsur kalium berperan dalam pertumbuhan vegetatif tanaman seperti memperkuat tegakan batang, juga meningkatkan kadar karbohidrat tanaman.

\section{Pertumbuhan tanaman kedelai}

Tinggi tanaman

Tinggi tanaman merupakan salah satu indikator pengamatan untuk melihat pertumbuhan tanaman kedelai. Hasil analisis ragam (ANOVA) menunjukkan hasil bahwa pemberian kombinasi kompos paitan dan kotoran sapi berpengaruh nyata terhadap tinggi tanaman kedelai pada pengamatan 35 dan 42 HST. Hasil pengamatan tinggi tanaman setelah diberi perlakuan kompos paitan dan kotoran sapi dapat dilihat pada Tabel 8.

Tabel 8. Pengaruh pemberian kompos paitan dan kotoran sapi terhadap tinggi tanaman kedelai.

\begin{tabular}{lccccc}
\hline Perlakuan & \multicolumn{5}{c}{ Tinggi Tanaman (cm) } \\
\cline { 2 - 6 } & 14 HST & 21 HST & 28 HST & 35 HST & 42 HST \\
\hline P0 (kontrol) & $14,43 \mathrm{a}$ & $20,50 \mathrm{a}$ & $31,67 \mathrm{a}$ & $39,17 \mathrm{a}$ & $45,00 \mathrm{a}$ \\
P1 $(100 \% \mathrm{KP})$ & $14,53 \mathrm{a}$ & $22,17 \mathrm{a}$ & $35,33 \mathrm{a}$ & $45,00 \mathrm{ab}$ & $48,50 \mathrm{ab}$ \\
P2 $(100 \% \mathrm{KKS})$ & $14,50 \mathrm{a}$ & $23,83 \mathrm{a}$ & $32,33 \mathrm{a}$ & $48,33 \mathrm{abc}$ & $52,50 \mathrm{ab}$ \\
P3 $(75 \% \mathrm{KP}+25 \% \mathrm{KKS})$ & $16,73 \mathrm{a}$ & $29,17 \mathrm{a}$ & $41,67 \mathrm{a}$ & $48,00 \mathrm{abc}$ & $57,33 \mathrm{~b}$ \\
P4 $(50 \% \mathrm{KP}+50 \% \mathrm{KKS})$ & $15,73 \mathrm{a}$ & $26,13 \mathrm{a}$ & $37,67 \mathrm{a}$ & $54,67 \mathrm{c}$ & $58,50 \mathrm{~b}$ \\
P5 (25\% KP+75\% KKS) & $14,83 \mathrm{a}$ & $26,30 \mathrm{a}$ & $36,00 \mathrm{a}$ & $50,90 \mathrm{bc}$ & $58,00 \mathrm{~b}$ \\
\hline
\end{tabular}

Keterangan: angka yang diikuti oleh huruf yang sama pada kolom yang sama menunjukkan hasil tidak berbeda nyata menurut uji DMRT taraf 5\%; KP: Kompos Paitan, KKS: Kompos Kotoran Sapi.

Tinggi tanaman pada setiap perlakuan masih mengalami peningkatan setiap minggunya. Tinggi tanaman kedelai tertinggi saat 14 HST yaitu pada perlakuan $\mathrm{P} 3$ sebesar $16,73 \mathrm{~cm}$ dan terendah yaitu pada perlakuan P0 sebesar 14,43 $\mathrm{cm}$. Tinggi tanaman tertinggi pada $42 \mathrm{HST}$ yaitu pada perlakuan $\mathrm{P} 4$ sebesar $58,5 \mathrm{~cm}$ dan terendah pada perlakuan P0 sebesar $45 \mathrm{~cm}$, sehingga penambahan kombinasi kompos paitan dan kotoran sapi dapat meningkatkan tinggi tanaman sebesar $30 \%$ pada umur 42 HST. Tidak adanya pengaruh nyata pemberian kompos paitan dan kotoran sapi pada umur 14 - 28 HST dapat karena sifat kompos yang slow release sehingga unsur hara dari kompos belum sepenuhnya tersedia dan dapat diserap oleh tanaman kedelai pada fase awal vegetatif, sedangkan pada fase akhir vegetatif unsur hara 


\section{Jurnal Tanah dan Sumberdaya Lahan Vol 8 No 1: 123-133, 2021 e-ISSN:2549-9793, doi: 10.21776/ub.jts1.2021.008.1.16}

pada kompos mulai tersedia dan dapat diserap oleh tanaman sehingga menunjukkan pengaruh yang nyata. Menurut Nuro et al. (2016), pupuk organik memiliki sifat slow release atau lambat tersedia sehingga pada umumnya tanaman akan menghasilkan produksi yang lebih baik pada musim tanam kedua sejak aplikasi pupuk organik tersebut khususnya ketersediaan $\mathrm{N}, \mathrm{P}$, dan $\mathrm{K}$ jika dibandingkan dengan pupuk anorganik. Baghdadi et al. (2018), menambahkan bahwa pupuk organik juga merupakan sumber nutrisi yang dapat membantu meningkatkan hasil panen, rendahnya hasil panen oleh pupuk organik dari pada pupuk kimia disebabkan oleh pelepasan unsur hara yang lambat. Lambatnya ketersediaan unsur hara memperkecil risiko kelebihan unsur hara, tetapi lambatnya unsur hara yang tersedia ini menyebabkan tidak terpenuhinya unsur hara saat dibutuhkan.

\section{Jumlah daun}

Berdasarkan hasil pengamatan dan analisis ragam (ANOVA) menunjukkan hasil bahwa pemberian kombinasi kompos paitan dan kotoran sapi berpengaruh nyata terhadap jumlah daun umur 35 dan 42 HST. Hasil pengamatan jumlah daun tanaman setelah diberi perlakuan kompos paitan dan kotoran sapi dapat dilihat pada Tabel 9. Pada pengamatan 14 HST jumlah daun terendah yaitu terdapat pada perlakuan P0 sebesar 3 dan tertinggi pada P5 sebesar 4, sedangkan pada pengamatan 42 HST jumlah daun terendah terdapat pada perlakuan P0 yaitu sebesar 7 dan tertinggi pada perlakuan P3 yaitu sebesar 14, sehingga penambahan kombinasi kompos paitan dan kotoran sapi dengan perbandingan 75:25 dapat meningkatkan jumlah daun sebesar $100 \%$ pada umur 42 HST.

Tabel 9. Pengaruh aplikasi kompos paitan dan kotoran sapi terhadap jumlah daun kedelai.

\begin{tabular}{lccccc}
\hline Perlakuan & \multicolumn{5}{c}{ Jumlah Daun (Helai Trifoliate) } \\
\cline { 2 - 6 } & 14 HST & 21 HST & 28 HST & 35 HST & 42 HST \\
\hline P0 (kontrol) & $3 \mathrm{a}$ & $5 \mathrm{a}$ & $5 \mathrm{a}$ & $7 \mathrm{a}$ & $7 \mathrm{a}$ \\
P1 $(100 \% \mathrm{KP})$ & $3 \mathrm{a}$ & $5 \mathrm{a}$ & $6 \mathrm{a}$ & $7 \mathrm{ab}$ & $12 \mathrm{bc}$ \\
P2 $(100 \% \mathrm{KKS})$ & $4 \mathrm{a}$ & $5 \mathrm{a}$ & $6 \mathrm{a}$ & $8 \mathrm{ab}$ & $10 \mathrm{~b}$ \\
P3 $(75 \% \mathrm{KP}+25 \% \mathrm{KKS})$ & $4 \mathrm{a}$ & $5 \mathrm{a}$ & $6 \mathrm{a}$ & $10 \mathrm{c}$ & $14 \mathrm{c}$ \\
P4 $(50 \% \mathrm{KP}+50 \% \mathrm{KKS})$ & $4 \mathrm{a}$ & $5 \mathrm{a}$ & $6 \mathrm{a}$ & $9 \mathrm{bc}$ & $12 \mathrm{bc}$ \\
P5 $(25 \% \mathrm{KP}+75 \% \mathrm{KKS})$ & $4 \mathrm{a}$ & $6 \mathrm{a}$ & $6 \mathrm{a}$ & $8 \mathrm{abc}$ & $12 \mathrm{bc}$ \\
\hline
\end{tabular}

Keterangan: angka yang diikuti oleh huruf yang sama pada kolom yang sama menunjukkan hasil tidak berbeda nyata menurut uji DMRT taraf 5\%; KP: Kompos Paitan, KKS: Kompos Kotoran Sapi.

Hasil di atas menunjukkan bahwa meskipun pemberian kombinasi kompos paitan dan kotoran sapi pada umur 14-28 HST tidak berpengaruh secara nyata tetapi tetap meningkat pada setiap pengamatan, sedangkan jumlah daun berpengaruh nyata pada umur 35 dan 42 HST karena unsur hara kompos paitan dan kotoran sapi mulai tersedia dan diserap oleh tanaman kedelai. Pemberian kompos paitan dan kotoran sapi yang tidak berpengaruh nyata pada fase vegetatif awal juga dapat disebabkan oleh adanya serangan hama ulat grayak (Spodoptera litura) yang menyerang daun saat berumur 21, 28, dan 35 HST. Intensitas serangan tertinggi berada pada perlakuan $\mathrm{P} 0$ yaitu sebesar 35,83\% (21 HST); 24,58\% (28 HST); 25,35\% (35 HST) dan intensitas serangan terendah saat tanaman berumur 21 dan 28 HST terdapat pada perlakuan P1 yaitu sebesar 8,33\% (21 HST); $11,25 \%$ (28 HST). Pada umur 35 HST, intensitas serangan hama terendah yaitu pada perlakuan P3 yaitu sebesar 13,38\%. Intensitas serangan yang tinggi tersebut didominasi oleh kontrol atau tanpa pemberian kompos paitan dan kotoran sapi, sedangkan intensitas serangan terendah pada perlakuan yang didominasi oleh penambahan kompos paitan. Daun paitan mengandung senyawa aktif yang dapat menghentikan aktivitas makan yang dinamakan senyawa flavonoid, alkaloid, dan tanin. Hal ini sejalan dengan penelitian Sapoetro et al. (2019), yang menyatakan bahwa selain menimbulkan mortalitas, kandungan daun paitan juga mempengaruhi pertumbuhan dan perkembangan $S$. litura yang dinyatakan larva mengalami kecacatan. 


\section{Jurnal Tanah dan Sumberdaya Lahan Vol 8 No 1: 123-133, 2021 e-ISSN:2549-9793, doi: 10.21776/ub.jts1.2021.008.1.16}

\section{Jumlab cabang}

Berdasarkan hasil pengamatan dan analisis ragam (ANOVA) menunjukkan hasil bahwa pemberian kombinasi kompos paitan dan kotoran sapi tidak. berpengaruh nyata terhadap jumlah cabang tanaman kedelai pada setiap waktu pengamatan. Pada 42 HST jumlah cabang tertinggi yaitu terdapat pada perlakuan P4 sebesar 8 dan terendah pada perlakuan P0 sebesar 6, sehingga pemberian kombinasi kompos paitan dan kotoran sapi dengan perbandingan 50:50 dapat meningkatkan jumlah cabang sebesar 33,33\%. Pemberian kompos yang tidak berpengaruh nyata terhadap jumlah cabang karena unsur hara yang dibutuhkan dalam pembentukan cabang belum memenuhi kebutuhan unsur tanaman kedelai. Adapun unsur yang dimaksud yaitu fosfor, pada analisis dasar tanah Alfisol Jatikerto didapatkan nilai P tersedia sebesar 3,77 $\mathrm{ppm}$ dengan kategori sangat rendah sedangkan unsur fosfor yang dibutuhkan tanaman kedelai yaitu sebesar 11-15 ppm dengan kategori tinggi (Sumarno dan Ahmad, 2016). Hal ini sejalan dengan penelitian
Fahrizal et al. (2017), yang menyatakan bahwa jumlah cabang produktif dipengaruhi oleh pemberian dosis pupuk fosfor karena diduga dapat membantu pembentukan cabang baru.

\section{Hubungan sifat kimia dan pertumbuhan tanaman kedelai}

Pertumbuhan tanaman kedelai dipengaruhi salah satunya oleh faktor unsur hara. Penelitian melihat keterkaitan antara sifat kimia tanah terhadap pertumbuhan tanaman kedelai. Berikut merupakan tabel hasil analisis korelasi sifat kimia tanah dan pertumbuhan tanaman kedelai. Hasil analisis korelasi menunjukkan bahwa terdapat hubungan antar parameter yang diamati pada sifat kimia tanah dan pertumbuhan tanaman kedelai yang disajikan pada (Tabel 10). Kandungan C-organik menunjukkan hasil korelasi yang positif dengan hubungan yang cukup terhadap tinggi tanaman $(r=0,53)$ dan jumlah daun $(\mathrm{r}=0,58)$, hal ini menunjukkan bahwa semakin tinggi kandungan C-organik maka akan sejalan dengan peningkatan tinggi tanaman dan jumlah daun.

Tabel 10. Analisis korelasi sifat kimia tanah dan pertumbuhan tanaman kedelai.

\begin{tabular}{lclllll}
\hline Parameter & C-organik & \multicolumn{1}{c}{$\mathbf{p H}$} & K-dd & $\begin{array}{c}\text { Tinggi } \\
\text { Tanaman }\end{array}$ & $\begin{array}{c}\text { Jumlah } \\
\text { Daun }\end{array}$ & $\begin{array}{c}\text { Jumlah } \\
\text { Cabang }\end{array}$ \\
\hline C-organik & - & & & & & \\
pH & $0,57^{* * *}$ & - & & & & \\
K-dd & $0,51^{* * *}$ & $0,60^{* * * *}$ & - & & & \\
Tinggi Tanaman & $0,53^{* * *}$ & $0,57^{* * *}$ & $0,35^{* *}$ & - & & \\
Jumlah Daun & $0,58^{* * *}$ & $0,67^{* * * *}$ & $0,51^{* * *}$ & $0,83^{* * * * *}$ & - & \\
Jumlah Cabang & $0,22^{* *}$ & $0,50^{* * *}$ & $0,15^{*}$ & $0,43^{* * *}$ & $0,58^{* * *}$ & - \\
\hline
\end{tabular}

Keterangan: $* * * * *=$ korelasi positif hubungan sangat kuat; $* * * *=$ korelasi positif hubungan kuat; $* * *=$ korelasi positif hubungan cukup; $* *=$ korelasi positif hubungan lemah; $*=$ korelasi positif hubungan sangat lemah (Riduwan, 2010).

Kesuburan tanah mengacu pada kemampuan tanah untuk mendukung dan menopang pertumbuhan tanaman termasuk penyediaan nitrogen, fosfor, sulfur, dan unsur hara tersedia lainnya untuk diserap oleh tanaman, proses tersebut difasilitasi salah satunya oleh penyimpanan unsur hara dalam bahan organik (Clara et al., 2017). Korelasi positif dengan hubungan yang rendah terhadap jumlah cabang $(\mathrm{r}=0,22)$, artinya semakin besar kandungan $\mathrm{C}$ organik dalam tanah maka akan diikuti dengan peningkatan jumlah cabang namun hubungannya lemah. Menurut Blanco-Canqui et al. (2013), manfaat C-organik tanah pada tanaman tidak mudah diperhitungkan karena terdapat beberapa pengaruh dari penganggu tanaman lain terhadap faktor produksi. Corganik tanah dapat memperbaiki sifat-sifat tanah seperti makroporositas, stabilitas agregat, kompaktibilitas, infiltrasi air, kapasitas penahan air tanah, siklus nutrisi, $\mathrm{pH}$, serta pertukaran ion yang dapat meningkatkan produktivitas tanah dan meningkatkan produksi tanaman. $\mathrm{pH}$ tanah juga berkorelasi positif terhadap pertumbuhan 


\section{Jurnal Tanah dan Sumberdaya Lahan Vol 8 No 1: 123-133, 2021 e-ISSN:2549-9793, doi: 10.21776/ub.jts1.2021.008.1.16}

tanaman kedelai. $\mathrm{pH}$ tanah berkorelasi positif dengan hubungan cukup terhadap tinggi tanaman $(r=0,57)$ dan jumlah cabang $(r=0,50)$, serta berkorelasi positif terhadap jumlah daun dengan hubungan kuat $(r=0,67)$. Hubungan tersebut menunjukkan bahwa peningkatan $\mathrm{pH}$ sejalan dengan peningkatan tinggi tanaman, jumlah daun, dan jumlah cabang. Pemberian kompos dapat meningkatkan $\mathrm{pH}$ tanah menuju netral, $\mathrm{pH}$ tanah netral akan meningkatkan kandungan unsur hara tersedia dalam tanah, sehingga akan diikuti oleh peningkatan parameter pertumbuhan tanaman tersebut. Hal ini sejalan dengan pendapat Triadiati et al. (2013), bahwa aplikasi kompos dapat meningkatkan $\mathrm{pH}$ tanah dan mampu meningkatkan kandungan unsur hara tersedia dalam tanah serta mengikat $\mathrm{Al}$ di tanah masam. Kompos di dalam tanah akan terdekomposisi dan menghasilkan asam organik yang dapat mengikat $\mathrm{Al}$, bahan organik yang terkandung dalam kompos mengandung karbon yang dimanfaatkan untuk pertumbuhan mikroorganisme sehingga aktivitas mikroorganisme akan meningkat dan berdampak positif pada mineralisasi unsur hara, kemudian ketersediaan unsur hara bagi tanaman akan meningkat diikuti dengan meningkatnya pertumbuhan tanaman.

Terdapat korelasi antara kandungan K-dd tanah terhadap pertumbuhan tanaman kedelai. K-dd tanah berkorelasi positif terhadap tinggi tanaman dengan hubungan yang lemah ( $\mathrm{r}=$ $0,35)$, berkorelasi positif dengan hubungan cukup terhadap jumlah daun $(\mathrm{r}=0,51)$, serta berkorelasi positif dengan hubungan sangat lemah terhadap jumlah cabang $(r=0,15)$. Peran kalium dalam tanaman berkaitan dengan proses biofisika dan biokimia. Dalam proses biofisika, kalium berfungsi untuk mengatur tekanan osmosis dan tugor yang akan mempengaruhi pada pertumbuhan dan perkembangan sel serta membuka dan menutupnya stomata, sedangkan proses biokimia kalium berkaitan dengan 60 macam enzimatis untuk metabolisme karbohidrat dan protein (Subandi, 2013). Adisarwanto (2004), menambahkan bahwa peran ion kalium dalam tanah sangat penting karena mempengaruhi proses metabolisme, fisiologi, dan nutrisi, serta dibutuhkan dalam jumlah yang banyak untuk mencapai tingkat produksi yang tinggi.

\section{Kesimpulan}

Aplikasi kompos paitan dan kotoran sapi memberikan pengaruh yang nyata terhadap sifat kimia tanah Alfisol antara lain $\mathrm{pH}, \mathrm{C}$-organik, dan K-dd pada 0 dan 45 HST. Aplikasi berbagai kombinasi kompos paitan dan kotoran sapi berpengaruh nyata terhadap tinggi tanaman dan jumlah daun pada umur 35 dan 42 HST, namun tidak berpengaruh nyata terhadap jumlah cabang. Terdapat korelasi positif antara parameter sifat kimia tanah terhadap pertumbuhan tanaman kedelai. Parameter Corganik memiliki hubungan yang cukup kuat terhadap tinggi tanaman $(\mathrm{r}=0,53)$ dan jumlah daun $(r=0,58)$, dan hubungan yang lemah terhadap jumlah cabang $(\mathrm{r}=0,22)$.

\section{Daftar Pustaka}

Adisarwanto, T. 2004. Efisiensi penggunaan pupuk kalium pada kedelai di lahan sawah. Buletin Palawija 7(8): 31 - 39 .

Afandi, F.N., Siswanto, B. dan Nuraini, Y. 2015. Pengaruh pemberian berbagai jenis bahan organik terhadap sifat kimia tanah pada pertumbuhan dan produksi tanaman ubi jalar di Entisol Ngrangkah Pawon, Kediri. Jurnal Tanah dan Sumberdaya Lahan 2(2): 237-244.

Agustin, S.E., dan Suntari, R. 2018. Pengaruh aplikasi urea dan kompos terhadap sifat kimia tanah serta pertumbuhan jagung (Zea mays L.) pada tanah terdampak erupsi Gunung Kelud. Jurnal Tanah dan Sumberdaya Lahan 5(1): 775 - 783.

Antonius, S., Sahputra, R.D., Nuraini, Y. dan Dewi, K.T. 2018. Manfaat pupuk organik hayati, kompos dan biochar pada pertumbuhan bawang merah dan pengaruhnya terhadap biokimia tanah pada percobaan pot menggunakan tanah Ultisol. Jurnal Biologi Indonesia 14(2): 243-250.

Arifiati, A., Syekhfani., dan Nuraini, Y. 2017. Uji efektivitas perbandingan bahan kompos paitan (Tithonia diversifolia), tumbuhan paku (Dryopteris Filixmas), dan kotoran kambing terhadap serapan $\mathrm{N}$ tanaman jagung pada Inceptisol. Jurnal Tanah dan Sumberdaya Lahan 4(2): 543 - 552.

Baghdadi, A., Hali., R.A., Ghasemzadeh, A., Ramlan, M.F. and Sakimin, S.Z. 2018. Impact of organic and inorganic fertilizers on the yield and quality of silage corn intercropped with soybean. Peerj 6:E5280; doi 10.7717/Peerj.5280.

Balai Penelitian Tanah. 2005. Analisis Kimia Tanah, Tanaman, Air, dan Pupuk. Bogor, Badan Penelityian dan Pengembangan Pertanian, Departmen Pertanian. 


\section{Jurnal Tanah dan Sumberdaya Lahan Vol 8 No 1: 123-133, 2021 e-ISSN:2549-9793, doi: 10.21776/ub.jts1.2021.008.1.16}

Berlian, Z., Syarifah., dan Sari, D.S. 2015. Pengaruh pemberian limbah kulit kopi (Coffea robusta L.) terhadap pertumbuhan cabai keriting (Capsicum annum L.). Jurnal Biota 1(1): 22-32.

Blanco-Canqui, H., Shapiro, C.A., Wortmann, C., Drijber, R.A., Mamo, M., Shaver, T.M $>$ and Ferguson, R.B. 2013. Soil organic carbon: the value to soil properties. Journal of Soil and Water Conservation 68(5): 129A-134A.

Clara, L., Rekik, F., Alcantara, V. and Wiese, L. 2017. Soil Organic Carbon: The Hidden Potential. Rome: Food and Agriculture Organization of the United Nations.

Darmawan, F. dan Soemarno. 2000. Analisis kesesuan lahan bagi usaha tani tebu dan kedelai di Wilayah Kecamatan Kromengan, Kabupaten Malang. Agritek 8(4): 490-500.

Fahrizal, I., Rahayu, A. dan Rohman, N. 2017. Respon tanaman kedelai terhadap inokulasi mikoriza arbuskula dan pemberian pupuk fosfor pada tanah masam. Jurnal Agronida 3(2): 95-106.

Handayanto, E., Muddarisna, N. dan A. Fiqri. 2017. Pengelolaan Kesuburan Tanah. Malang: UB Press.

Lestari, S.A.D. 2016. Pemanfaatan paitan (Tithonia diversifolia) sebagai pupuk organik pada tanaman kedelai. Iptek Tanaman Pangan 11(1): 49 - 55.

Muktiyanta., Samanhudi., Yunus, A., Pujiasmanto, B. and S. Minardi. 2018. Effectiveness of cow manure and mycorrhiza on the growth of soybean. IOP Conference Series: Earth And Environmental Science 142:1-7.

Nuraini, Y. 2012. Efektivitas berbagai Kompos dalam Stimulasi Mikroorganisme N, P, dan Hormon Pertumbuhan sebagai Upaya Perbaikan Kesuburan Tanah untuk Peningkatan Produksi Kedelai di Lahan Kering. Disertasi. Malang: Universitas Brawijaya.

Nuro, F., Priadi, D. dan Mulyaningsih, E.S. 2016. Efek Pupuk Organik terhadap Sifat Kimia Tanah dan Produksi Kangkung Darat (Ipomoea reptans Poir.). Prosiding Seminar Nasional Hasil-Hasil PPM IPB 29-39.

Refliaty., Tampubolon, G, dan Hendriansyah. 2011. Pengaruh pemberian kompos sisa biogas kotoran sapi terhadap perbaikan beberapa sifat fisik Ultisol dan hasil kedelai (Glycine Max (L.) Merill). Jurnal Hidrolitan 2(3): $103-114$.

Rohmah, E.A dan Saputro, T.B. 2016. Analisis pertumbuhan tanaman kedelai (Glycine Max L.) varietas Grobogan pada kondisi cekaman genangan. Jurnal Sains dan Seni ITS 5(2): 29 - 33.
Sapoetro, T.S., Hasibuan, R., Hariri, A.M. dan Wibowo, L. 2019. Uji potensi daun kipahit (Tithonia diversifolia A. Gray) sebagai insektisida botani terhadap larva Spodoptera litura F. di laboratorium. Jurnal Agrotek Tropika 7(3): 371381.

Setyorini, D., Saraswarti, R. dan Anwar, E.A. 2006. Pupuk Organik dan Pupuk Hayati. Bogor: Balai Besar Penelitian dan Pengembangan Sumberdaya Lahan Pertanian. Hal 11-40.

Subandi. 2013. Peran dan Pengelolaan Hara Kalium untuk Produksi Pangan Di Indonesia. Pengembangan Inovasi Pertanian 6(1): 1-10.

Sumarni, T., Fajriani, S. dan Effendi, O.W. 2012. Respons Tanaman Kedelai terhadap Pemberian Pupuk Fosfor dan Pupuk Hijau Paitan. Prosiding Seminar Hasil Penelitian Tanaman Aneka Kacang dan Umbi.

Sumarno dan Ahmad, G.M. 2016. Persyaratan Tumbuh dan Wilayah Produksi Kedelai di Indonesia. Bogor: Pusat Penelitian dan Pengembangan Tanaman Pangan.

Taufiq, A dan Sundari, T. 2012. Respons tanaman kedelai terhadap lingkungan tumbuh. Buletin Palawija (23): 13 - 26.

Triadiati., Mubarik, N.R. dan Romasita, Y 2013. Respon pertumbunan tanaman kedelai terhadap Bradyrbizobium japonicum toleran masam dan pemberian pupuk di tanah masam. Jurnal Agronomi Indonesia 41(1): 24-31.

Wahyunie, E.D., Baskoro, D.P.T. dan Sofyan, M. 2012. Kemampuan retensi air dan ketahanan penetrasi tanah pada sistem olah tanah intensif dan olah tanah konservasi. Jurnal Tanah Lingkungan 14(2): 73-78.

Wahyuningsih, S. 2019. Buletin Konsumsi Pangan. Pusat Data dan Sistem Informasi Pertanian Sekretariat Jendral Kementerian Pertanian 10(1): 36- 46.

Widodo, K.H. dan Kusuma, Z. 2018. Pengaruh kompos terhadap sifat fisik tanah dan pertumbuhan tanaman jagung di Inceptisol. Jurnal Tanah dan Sumberdaya Lahan 5(2): 959967.

Yuwono, M., Basuki, N., dan Agustin, L. 2012. Pertumbuhan dan Hasil Ubi Jalar (Ipomoea Batatas L.) pada Macam dan Dosis Pupuk Organik yang Berbeda terhadap Pupuk Anorganik. Yogyakarta: Kanisius. 